Research Paper

\title{
Eucalyptus grandis Hill ex Maiden inoculated with Pisolithus microcarpus (UFSC-Pt116) in land subject to the sandy process in Southern Brazil
}

\author{
Eduardo Lorensi de Souza, Zaida Inês Antoniolli, Rafael Goulart Machado, \\ Daniel Pazzini Eckhardt, Sabrina de Fátima Barbosa Dahmer \\ Laboratório de Microbiologia do Solo e do Ambiente, Departamento de Solos, \\ Universidade Federal de Santa Maria, Santa Maria, RS, Brazil.
}

Submitted: October 14, 2011; Approved: November 14, 2014.

\begin{abstract}
Eucalypts is one of the main species used for commercial reforestation in the Rio Grande do Sul State, Brazil. This study aimed to evaluate the survival and early growth of eucalyptus trees in an area subject to sandy process after three years of growth. The Eucalyptus grandis seedlings were grown in a greenhouse, inoculated or not with the isolated ectomycorrhizal Pisolithus microcarpus (UFSCPt116), produced in peat or Entisol. After 120 days, the seedlings were transplanted to an area subject to the sandy process, in the São Francisco de Assis city, RS. The plants have been evaluated regarding survival, height, stem diameter, nitrogen, phosphorus and potassium levels and total phosphorus, inorganic phosphorus, organic phosphorus and wood production on different days after planting. The seedlings grown on the Entisol which was inoculated with the isolated UFSC-Pt116 presented higher survival rates, height, stem diameter, nitrogen concentration and wood production then noninoculated seedlings. Inoculation with ectomycorrhizal fungi enhanced the production of E. grandis seedlings in survival rates, height, stem diameter.
\end{abstract}

Key words: ectomycorrhiza, degraded areas, Entisol, inoculation.

\section{Introduction}

In the southwestern state of Rio Grande do Sul (RS), Brazil, there are areas with Entisol subject to sandy process, and its occurrence is associated with the sandstone substrate, mapped and known in this region as Botucatu formation, with sparse vegetation, predominately grass. In the 1970s, Moller et al. (1975) stated there were in this region, in the city of São Francisco de Assis, approximately 432 ha of sandy area. Recent data indicate an advance of this degradation process, with an area of approximately $720 \mathrm{ha}$. It is estimated that there are more than 5,000 hectares covered by dunes, in an area that includes ten cities in this region, among them, São Francisco de Assis. The weakness of soil comes from its difficulty in compensating for the disruption imposed by human action, noted by the natural susceptibility to water and wind erosion, which contributes to its degradation.
The characteristics of this soil make its economic and/or ecological use very difficult. Thus, these areas are being designed for the planting of Forest species, such as eucalypts, pine and black acacia. However, the difficulty of sand soils in retaining water and nutrients is the main factor that hampers the maintenance and development of the vegetation, and it is important to search for alternatives based on the production of seedlings in fertile substrates and inoculated with ectomycorrhizal fungi.

Eucalypts trees can form two types of mycorrhizal association; the arbuscular and the ectomycorrhiza (Zambolim and Barros, 1982), the ectomycorrhizae being the most common, which are responsible for the establishment of this species in nutrient-poor soils. The presence of these fungi on plants supports the establishment and survival of the plant in the field by increasing the absorption of nutrients, increasing root longevity, protecting against pathogens, and increasing dry matter and phosphorus uptake (Barros et al., 1978).

Send correspondence to E.L. Souza. Laboratório de Microbiologia do Solo e do Ambiente, Departamento de Solos, Universidade Federal de Santa Maria, Santa Maria, RS, Brazil. E-mail: elorensi@yahoo.com.br. 
The importance of ectomycorrhizal fungi for the growth and development of eucalypts seedlings is well documented. Although experiments performed in greenhouses provide evidence for the need for inoculation of seedlings, there are only a few studies that demonstrate the suitability of this inoculation in order to enhance the performance of seedlings in the field. The ectomycorrhizal fungi are physiologically and ecologically diverse, and a strong ecotype variation can be found among isolates of the same species (Trappe and Fogel, 1977). Based on the variation between the mycorrhizal fungi on the ability to colonize the seedlings of eucalypts, it is necessary to test the isolated, after its selection, for its efficiency in promoting the growth of seedlings in the field, especially in the areas of settlement implementation.

The need to produce seedlings designed for specific areas, with defined characteristics, is due to the fact that these seedlings are generally weak, which demands early protection and appropriate handling to achieve greater uniformity of growth. To be successful in the implementation of eucalyptus seedlings in areas subject to sandy process, it is necessary that the plants grow in soil with sufficient nutrients for the initial boot.

This study aimed to evaluate the survival, growth and the development of Eucalyptus grandis inoculated with the ectomycorrhizal fungus Pisolithus microcarpus (UFSCPt116), as well as verifying whether the inoculation with fungus modifies the nutrients and fractions of phosphorus stored in the leaves.

\section{Material and Methods}

\section{Isolated ectomycorrhizal fungi}

The isolated ectomycorrhizal fungus that was tested in this experiment was the Pisolithus microcarpus (Cooke and Massee) Cunn (UFSC-Pt116) which originated from Eucalyptus spp. plantations, submitted by Prof. Dr. Vetúria Lopes de Oliveira from the Ectomycorrhizae Lab of the Department of Microbiology and Parasitology, Federal University of Santa Catarina.

The isolated fungus was multiplied in the Laboratory of Biology and Microbiology of Soil and Environment in the Department of Soil at Santa Maria Federal University (UFSM).

It was maintained in solid Modified Melin-Norkrans medium (MMN) (Marx, 1969), in Petri dishes, in oven at $25^{\circ} \mathrm{C}$. Subsequently, the isolate was multiplied from cultures of the collection, by means of sub culturing to the medium of the same composition, under aseptic conditions.

\section{Production of ectomycorrhizal fungus inoculum}

To produce the inoculum of ectomycorrhizal fungi (ECMf), mycelian suspensions were made in $25 \mathrm{~mL}$ of liquid MMN medium in $250 \mathrm{~mL}$ Erlenmeyer flasks, from discs of $8 \mathrm{~mm}$ in diameter, obtained from plate cultures, followed by incubation at $25^{\circ} \mathrm{C}$ for 30 days.

After this period, the contents of two Erlenmeyer flasks were fragmented in $200 \mathrm{~mL}$ of liquid MMN medium in a blender for $5 \mathrm{~s}$, and then used to make $500 \mathrm{~mL}$ of a peat: vermiculite mixture (4:1) (V/V) added to $200 \mathrm{~mL}$ of liquid MMN medium, in glass flasks of $900 \mathrm{~mL}$, which were previously sterilized in autoclave at $121^{\circ} \mathrm{C}$, for $60 \mathrm{~min}$. The flasks were kept in an oven at $25{ }^{\circ} \mathrm{C}$ for the mycelium growth for 90 days.

\section{Substrate for planting eucalypts seedlings}

The planting substrates were composed by peat (Florestal S.A) or Entisol mixed with vermiculite. The peat composition presented the following chemical characteristics: $\mathrm{pH}=6.5 ; \mathrm{P}=39.55 \mathrm{mg} / \mathrm{L} ; \mathrm{K}=82 \mathrm{mg} / \mathrm{L} ; \mathrm{Al}=0$; $\mathrm{Ca}=5.3 \mathrm{cmolc} / \mathrm{dm} 3$ and $\mathrm{Mg}=3.3 \mathrm{cmol}_{\mathrm{c}} / \mathrm{L}$. The proportion of the substrate was four parts of peat and one part of vermiculite $(\mathrm{v} / \mathrm{v})$. The Entisol presented the following chemical characteristics: $\mathrm{pH}=4.7 ; \mathrm{P}=8 \mathrm{mg} / \mathrm{L} ; \mathrm{K}=30 \mathrm{mg} / \mathrm{L} ; \mathrm{Al}=$ $0.6 \mathrm{cmol}_{\mathrm{c}} / \mathrm{L} ; \mathrm{Ca}=0.3 \mathrm{cmol}_{\mathrm{c}} / \mathrm{L} \mathrm{e} \mathrm{Mg}=0.1 \mathrm{cmol}_{\mathrm{c}} / \mathrm{L}$ and it was also mixed with the vermiculite in the proportion of $(1: 3)(V / V)$. Both peat and Entisol substrates had been previously sterilized in autoclave at $121{ }^{\circ} \mathrm{C}$ for $60 \mathrm{~min}$, three consecutive times, with a 24 -hour pause between each sterilization. A nutritive solution was added to the substrates that contained the following elements: $\mathrm{K}, 16$; Mn, 0.15 ; $\mathrm{Mg}, 3 ; \mathrm{Zn}, 0.0375 ; \mathrm{Cu}, 0.125 ; \mathrm{Mo}, 0.05 ; \mathrm{B}, 0.05$ e Fe, 0.375 $(\mathrm{mg} / \mathrm{kg})$ (Alves et al., 2001).

\section{Seeds}

The seeds of Eucalyptus grandis were obtained from the State Foundation for Agricultural Research (Fundação Estadual de Pesquisa Agropecuária) - FEPAGRO - Florestas, Santa Maria/RS. They were first sterilized in Alcohol $(70 \%)$ for $30 \mathrm{~s}$, rinsed in distilled water and transferred to a germination solution of boric acid $(3 \mu \mathrm{M})$, glucose $(2 \mathrm{~g} / \mathrm{L})$ and calcium sulfate $(500 \mu \mathrm{M})$, at $5.7 \mathrm{pH}$, and kept under stirring for 3 days.

\section{Cultivation of eucalypts seedlings}

The inoculation with Pisolithus microcarpus (UFSC-Pt116) took place at the time of sowing, adding $10 \%(\mathrm{v} / \mathrm{v})$ of inoculant, previously washed with distilled water (Alves et al., 2001). The inoculum homogenization was performed manually, using disposable gloves. The control treatment received the same amount of the uninoculated peat-vermiculite-MMN mixture, and it was subject to the same maintenance conditions as the inoculated material.

The eucalypts seedlings were produced in plastic pots inside greenhouses. The inoculated substrates had been previously homogenized and after, distributed in conical PVC tubes of $50 \mathrm{~cm}^{3}$ that were disinfected with sodium hypochlorite solution $1 \%$. Each tube received five seeds of 
Eucalyptus, placed about $1 \mathrm{~cm}$ deep, and recoated with the substrate. After that, the contents of the tubes were moistened with distilled water.

The treatments were arranged in a randomized design, with weekly rotation of tubes with 10 repetitions. Four weeks after sowing, when the seedlings had one pair of definite leaves, thinning was performed, keeping one seedling per tube.

For the purpose of testing, seven different doses of phosphorus had been added to the planting substrate: $0 ; 25$; $50 ; 100 ; 200,400,800 \mathrm{mg} / \mathrm{kg}$, based on preliminary studies of Alves et al. (2001). In this study, soluble $\mathrm{P}$ was used in the form of $\mathrm{Ca}\left(\mathrm{H}_{2} \mathrm{PO}_{4}\right)_{2} \cdot \mathrm{H}_{2} \mathrm{O}$, administered in solution to the planting substrate of the seeds. After harvesting the seedlings, the phosphorus available had been extracted using the Mehlich 1 method, corresponding, respectively, to the doses of $0.5 ; 4.8 ; 8.8 ; 15.4 ; 33 ; 140$ and $310 \mathrm{mg} \mathrm{kg}^{-1}$ on the peat substrate and $0.3 ; 3.7 ; 7.5 ; 13.2 ; 21 ; 110$; $280 \mathrm{mg} / \mathrm{kg}$ on the Entisol.

After inoculation and sowing, the seedlings were kept in a greenhouse for 120 days and moisture was kept by adding $50 \mathrm{~mL}$ of distilled water daily, according to Mello (2006).

\section{Seedling planting in the field}

The experiment was performed on August, 2005, at the Ynhacundá Farm, located in the city of São Francisco de Assis, RS, Brasil, 62 meters altitude, 2313'25.2” South

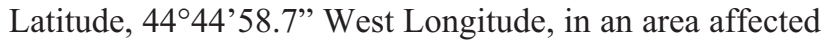
by sandy process. The soil was classified as Entisol, which showed the following chemical characteristics: $\mathrm{pH}=5.1$; $\mathrm{Al}=0.5 \mathrm{cmol}_{\mathrm{c}} / \mathrm{L} ; \mathrm{Ca}+\mathrm{Mg}=0.5 \mathrm{cmol}_{\mathrm{c}} / \mathrm{dm} ; \mathrm{P}=8.0 \mathrm{mg} / \mathrm{L}$ (Mehlich -1 ) and $\mathrm{K}=48 \mathrm{mg} / \mathrm{L}$.

The seedlings transplanted to the field were from the substrate $\mathrm{x}$ fungus $\mathrm{x}$ phosphorus level treatment which best reacted in a greenhouse to the assessed growth parameters, such as height, diameter and percentage of ectomycorrhizal colonization, corresponding to the dose of $50 \mathrm{mg} \mathrm{kg}^{-1}$ phosphorus, according to Mello (2006). These seedlings were transplanted in holes of $20 \mathrm{~cm} \mathrm{x} 20 \mathrm{~cm}$ and fertilized with NPK 3010 30, following the recommendation of Gonçalves (1994). 120 days after transplanting (DAT), a new fertilization was carried out by adding $100 \mathrm{~g}$ of NPK in each hole, with the same previous formulation.

The experiment in the field was performed through randomized block design with four treatments: peat with and without fungus and Entisol with and without fungus, with four replications. Each block consisted of 64 seedlings, 16 of each treatment, arranged in four rows spaced $1.5 \times 1.5 \mathrm{~m}$.

After planting, each seedling was irrigated with $5 \mathrm{~L}$ of water. Due to the presence of leaf-cutter ants, every 15 days Klap ${ }^{\circledR}$ anticide was applied (Fenil Pirazol) in the solution.

Evaluations were performed at 90, 120, 360, 720 and 960 days after planting (DAP), analyzing the survival, height, stem diameter, nitrogen, phosphorus and potassium concentration, the concentrations of total soluble phosphorus, inorganic and organic phosphorus and the production of wood from eucalypts trees.

Physiologically mature leaves were collected from each plant for the fractionation of $\mathrm{P}$. Those samples were placed in $0.2 \mathrm{~N}$ perchloric acid and frozen in order to be later analyzed regarding total acid-soluble P (Pts), inorganic acid-soluble $\mathrm{P}(\mathrm{Pi})$, and by difference, organic acidsoluble $\mathrm{P}(\mathrm{Po})$ (Hogue et al., 1970). The chemical determinations of $\mathrm{N}, \mathrm{P}$ and $\mathrm{K}$ were conducted according to Tedesco et al. (1995).

The production of wood was calculated using the following equations: $V=a b \cdot h \cdot F c$ and $A b=d^{2} \cdot \pi / 4$ where $V=$ volume (cm3), $A b=$ base area $(\mathrm{cm} 2), h=$ height $(\mathrm{m})$, $F c=$ correction factor $(0.5), d=$ diameter $(\mathrm{cm} 2)$ and $\pi=3.14$ (Shimizu and Carvalho, 2000).

The results of survival, height, stem diameter, nitrogen, phosphorus and potassium concentrations, total soluble phosphorus, inorganic phosphorus, organic phosphorus and wood production were tested for normality and subjected to analysis of variance and to the range test (Tukey, $5 \%$ ), using the procedures available in the statistical SISVAR program (Ferreira, 2000).

\section{Results and Discussion}

Inoculation with the isolated ectomycorrhizal fungus Pisolithus microcarpus (UFSC-Pt116) helped to increase the rate of successful seedlings in the field and the survival rate in the inoculated treatments. For the treatment that received the peat substrate, the survival rate percentage was higher by 8 and $9 \%$ at 90 and 960 days after planting in the field, respectively, compared with the control treatment without inoculation. When using Entisol as the substrate, the survival rates of the Eucalyptus trees in the field increased by 9 and $22 \%$, compared to the control, at 90 and 960 days after the planting, respectively.

At 90 days after the planting, the percentage of live plants ranged between 89 and $100 \%$, whereas at 960 DAP this percentage ranged between 13 and 40\% (Table 1). Due to the attack of ants, the percentage of live plants declined throughout the experimental period.

The substrate used also contributed to the establishment of seedlings in the field after transplanting. After 960 days, treatment with peat containing fungus showed higher survival rates of Eucalyptus grandis seedlings compared to the Entisol. Plants that were inoculated with fungus presented the highest survival rates in the field due to the benefits promoted by the ectomycorrhizal fungus and to the type of substrate used.

These results highlight the importance of inoculating the eucalyptus seedlings with ectomycorrhizal fungi in their formation in the nurseries and/or greenhouses, as the mycorrhizal association brings benefits to the plants in the 
Table 1 - Survival plants percentage of Eucalyptus grandis produced in different substrates, inoculated and non-inoculated with ectomycorrhiza fungus Pisolithus microcarpus (UFSC-Pt116) at 90 and 960 days after the planting (DAP), in sandy area of São Francisco de Assis, RS.

\begin{tabular}{lcc}
\hline Treatments & 90 DAP & 960 DAP \\
\hline Peat with Fungus & $100 \mathrm{a}^{*}$ & $40 \mathrm{a}$ \\
Peat without Fungus & $92 \mathrm{c}$ & $31 \mathrm{c}$ \\
Entisol with Fungus & $98 \mathrm{~b}$ & $35 \mathrm{~b}$ \\
Entisol without Fungus & $89 \mathrm{~d}$ & $13 \mathrm{~d}$ \\
\hline
\end{tabular}

*Averages followed by the same letters in the columns do not differ statistically among each other by the Tukey test at $5 \%$ probability.

field, including the highest survival and resistance rates to biotic and abiotic factors, which affect their survival (Smith and Read, 1997).

At 120,360, 720 and 960 days after transplanting, the seedlings showed significant differences in height and stem diameter (Table 2). Plants inoculated with UFSC-Pt116 isolated and produced in the peat substrate showed the highest growth in height and diameter at 120 and 360 days after transplantation, followed by peat without fungus, Entisol with fungus and Entisol without fungus (Table 2). At 360 days after transplanting, plants inoculated with isolate UFSC-Pt116 and grown in peat substrate were 3.5 times higher than treatment with Entisol.

At 720 and 960 days after transplanting, the plants inoculated with UFSC-Pt116 and grown in the Entisol with Fungus substrate showed higher growth in height, followed by the peat with fungus treatment, peat without fungus and Entisol without fungus (Table 2). For the stem diameter, plants inoculated with the UFSC-Pt116 and produced in the Entisol with fungus, peat with and without fungus substrates showed no statistical difference, differing only from the Entisol without fungus treatment (Table 2). The plants

Table 2 - Height and stem diameter of the Eucalyptus grandis plants produced in different substrates, inoculated and non-inoculated with Pisolithus microcarpus (UFSC-Pt116) isolated at 120, 360, 720 and 960 days after the planting (DAP) in sandy area of São Francisco de Assis, RS.

\begin{tabular}{lcccc}
\hline \multirow{2}{*}{ Treatment } & \multicolumn{4}{c}{ Height (m) } \\
\cline { 2 - 5 } & 120 DAP & 360 DAP & 720 DAP & 960 DAP \\
\hline Peat with Fungus & $0.28 \mathrm{a}^{*}$ & $1.38 \mathrm{a}$ & $5.12 \mathrm{~b}$ & $5.73 \mathrm{~b}$ \\
Peat without Fungus & $0.27 \mathrm{~b}$ & $0.97 \mathrm{~b}$ & $4.01 \mathrm{~b}$ & $4.83 \mathrm{~b}$ \\
Entisol with Fungus & $0.22 \mathrm{~b}$ & $0.59 \mathrm{c}$ & $7.07 \mathrm{a}$ & $7.43 \mathrm{a}$ \\
Entisol without Fungus & $0.18 \mathrm{~b}$ & $0.39 \mathrm{c}$ & $0.69 \mathrm{c}$ & $1.80 \mathrm{c}$ \\
\hline & \multicolumn{5}{c}{ Stem diameter $(\mathrm{cm})$} \\
\hline Peat with Fungus & $0.60 \mathrm{a}$ & $2.20 \mathrm{a}$ & $4.65 \mathrm{a}$ & $7.65 \mathrm{a}$ \\
Peat without Fungus & $0.60 \mathrm{a}$ & $1.60 \mathrm{~b}$ & $5.35 \mathrm{a}$ & $8.35 \mathrm{a}$ \\
Entisol with Fungus & $0.50 \mathrm{a}$ & $1.10 \mathrm{~b}$ & $6.64 \mathrm{a}$ & $8.60 \mathrm{a}$ \\
Entisol without Fungus & $0.50 \mathrm{a}$ & $1.00 \mathrm{~b}$ & $1.60 \mathrm{~b}$ & $2.60 \mathrm{~b}$ \\
\hline
\end{tabular}

* Averages followed by the same letters in the columns do not differ statistically among each other by the Tukey test at $5 \%$ probability. with higher growth rates at 720 and 960 days were from the Entisol with Fungus treatment (Table 2), revealing that the plants which were grown in greenhouses with this substrate were more adapted for transplanting to the field, since Entisol is the soil of the area where the experiment was carried out. These results are similar to Souza (2004), in a study with Eucalyptus sp. and the ectomycorrhizal fungus UFSC-Pt116, working in a greenhouse. These results demonstrate the importance of producing mycorrhizal seedlings for specific areas, with defined characteristics, because these seedlings are usually fragile, requiring early protection and appropriate handling in order to achieve greater uniformity of growth.

To be successful in the implementation of eucalyptus seedlings in areas of sandy process, it is necessary for them to grow in soil with sufficient nutrients for the initial boot and for the colonization to occur, thus enabling the survival of seedlings in the post- planting (Galli et al., 1997). The results of this study confirm the importance of inoculating the Eucalyptus grandis seedlings with the isolated ectomycorrhizal Pisolithus microcarpus (UFSC-Pt116), because the seedlings with greater height, stem diameter and survival rate resisted better to the conditions of adversity shown in these areas, such as drought, low fertility and the presence of leaf-cutter ants.

Out of all the nutrients obtained from the leaves of Eucalyptus grandis, only the $\mathrm{N}$ presented significant variation, although in most of the treatments with the UFSCPt116 fungus inoculation, the concentrations of $\mathrm{P}$ and $\mathrm{K}$ were higher than in treatments without inoculation.

At 720 and 960 days after the transplantation, the plants inoculated with the isolated UFSC-Pt1 16 and grown in Entisol with fungus showed higher levels of $\mathrm{N}$ on the leaves (Table 3).

According to Mello (2006), species of ectomycorrhizal fungi found primarily in the area subject to sandy process in São Francisco de Assis were Pisolithus sp. Alb. and Schwein, Scleroderma sp. (Person) Fries and Pisolithus microcarpus (Cooke and Massee) Comm, and after three years of transplanting eucalyptus to this area, it was detected the presence of other species of mycorrhizal fungus, the Laccaria spp. The Eucalyptus spp. is a host of this fungus and may have colonized the eucalypts plants, benefiting the absorption of $\mathrm{P}$ and $\mathrm{K}$ and contributing to the nonsignificant results of $\mathrm{P}$ and $\mathrm{K}$ levels in shoots of noninoculated plants.

The results found in $\mathrm{P}$ and $\mathrm{K}$ levels corroborate those reported by Mello (2006), where there was no significant difference in the levels of these elements, working with the same experiment in Entisol, and by Silva et al. (2003), which also found no phosphorus accumulation in inoculated seedlings, working with Pinus elliottii Engelm in sandy soil.

From the results obtained, regarding the level of phosphorus fractions (Pts, Pi and Po) no significant differ- 
Table 3 - N, P and K levels on plant shoos of Eucalyptus grandis inoculated and no inoculated with Pisolithus microcarpus (UFSC-Pt116) isolated at 360, 720 and 960 days after the planting (DAP) in São Francisco de Assis, RS.

\begin{tabular}{|c|c|c|c|c|c|c|c|c|}
\hline \multirow{3}{*}{ Treatment } & \multicolumn{3}{|c|}{$\mathrm{N}(\mathrm{g} / \mathrm{kg})$} & \multicolumn{3}{|c|}{$P(g / k g)$} & \multicolumn{2}{|c|}{$\mathrm{K}(\mathrm{g} / \mathrm{kg})$} \\
\hline & \multicolumn{8}{|c|}{ DAP } \\
\hline & 720 & 960 & 360 & 720 & 960 & 360 & 720 & 960 \\
\hline Peat with Fungus & $15.2 b^{*}$ & $15.9 \mathrm{ab}$ & $1.4 \mathrm{a}$ & $5.5 \mathrm{a}$ & $3.0 \mathrm{a}$ & $5.4 \mathrm{a}$ & $12.7 \mathrm{a}$ & $15.1 \mathrm{a}$ \\
\hline Peat without Fungus & $15.4 \mathrm{~b}$ & $14.7 \mathrm{~b}$ & $1.2 \mathrm{a}$ & $5.4 \mathrm{a}$ & $3.0 \mathrm{a}$ & 4.9 a & $12.8 \mathrm{a}$ & $14.5 \mathrm{a}$ \\
\hline Entisol with Fungus & $19.6 \mathrm{a}$ & $17.6 \mathrm{a}$ & $1.3 \mathrm{a}$ & $5.4 \mathrm{a}$ & $2.8 \mathrm{a}$ & $4.4 \mathrm{a}$ & $11.4 \mathrm{a}$ & $13.8 \mathrm{a}$ \\
\hline Entisol without Fungus & $14.4 \mathrm{~b}$ & $15.4 \mathrm{~b}$ & $1.1 \mathrm{a}$ & $5.2 \mathrm{a}$ & $2.7 \mathrm{a}$ & $5.1 \mathrm{a}$ & $12.0 \mathrm{a}$ & $13.0 \mathrm{a}$ \\
\hline QV (\%) & 11.7 & 14.3 & 22.9 & 22.7 & 17.9 & 34.1 & 9.24 & 13.3 \\
\hline
\end{tabular}

*Averages followed by the same letters in the columns do not differ statistically among each other by the Tukey test at $5 \%$ probability.

ence was found $(\mathrm{p}<0.05)$ caused by inoculation with Pisolithus microcarpus (UFSC-Pt116) isolated and with the type of substrate used after three years of growth of $E u$ calyptus grandis in the area subject to sandy process (Table 4). However, the levels of Pts were different between treatments with and without inoculation, which ranged from 76 to $102 \mu \mathrm{g} / \mathrm{g}$ of fresh matter, showing the positive effect of inoculation of the fungus in the accumulation of this nutrient by the plant (Table 4).

In the treatments inoculated with UFSC-Pt116 isolated, an increase in Pi levels was observed, which ranged from 27.8 to $52.6 \mu \mathrm{g} / \mathrm{g}$ of fresh matter. The accumulation of $\mathrm{Pi}$ in the treatment with inoculated peat was almost double that obtained in the treatment with Entisol without the presence of fungus (Table 4). This shows that the inoculation favors the accumulation of $\mathrm{P}$ by the plant in the form of Pi, which is found in the cells vacuoles in the form of reserve (Bieleski, 1973; Bieleski and Ferguson, 1983). This means that when the supply of $\mathrm{P}$ is greater than the physiological demand of the plant, it is accumulated and stored in the vacuoles, representing a form of reserve for future use, if necessary.

Table 4 - Phosphorus fractions concentrations in plant shoot fresh matter of Eucalyptus grandis inoculated and non-inoculated with Pisolithus microcarpus (UFSC-Pt116) isolated at 960 days after transplanting in area subject to the sandy process in São Francisco de Assis, RS. Pts: total acid-soluble phosphorus; Pi: inorganic acid-soluble phosphorus; Po: organic acid-soluble phosphorus.

\begin{tabular}{lccc}
\hline Treatments & $\begin{array}{c}\text { Pts }(\mu \mathrm{g} / \mathrm{g} \text { of } \\
\text { fresh matter } \\
\text { of the plant } \\
\text { shoot) }\end{array}$ & Pi & Po \\
\hline Peat with Fungus & $102 \mathrm{a}^{*}$ & $52.6 \mathrm{a}$ & $49.6 \mathrm{a}$ \\
Peat without Fungus & $84 \mathrm{a}$ & $37.6 \mathrm{a}$ & $46.8 \mathrm{a}$ \\
Entisol with Fungus & $82 \mathrm{a}$ & $30.8 \mathrm{a}$ & $51.4 \mathrm{a}$ \\
Entisol without Fungus & $76 \mathrm{a}$ & $27.8 \mathrm{a}$ & $48.4 \mathrm{a}$ \\
$\mathrm{CV}(\%)$ & 48.2 & 95.4 & 43.7 \\
\hline
\end{tabular}

* Averages followed by the same letters in the columns do not differ statistically among each other by the Tukey test at $5 \%$ probability.
The highest levels of $\mathrm{P}$ accumulated in shoots of $\mathrm{Eu}$ calyptus grandis inoculated with the UFSC-Pt116 isolate indicates the efficiency of this isolate to enhance the absorption of this element by the plants, although it has not shown significant differences. In Eucalyptus grandis seedlings, Silva et al. (2007) found no significant difference $(\mathrm{p}<0.05)$ regarding phosphorus concentration in shoots of seedlings inoculated and non-inoculated with Pisolithus sp., which ranged from 0.3 to $0.6 \mathrm{mg} / \mathrm{g}$ after 105 days. The observation focused only on changes in the increase of $\mathrm{P}$ levels in shoots of seedlings with an increasing dose of the $P$ added.

A study carried out with seedlings of Eucalyptus dunnii Maiden, inoculated with the ectomycorrhizal Pisolithus microcarpus UFSC-Pt188 isolated, found that, besides the recovery of any P added $(50 \mathrm{mg} / \mathrm{kg}$ ) (Souza et al., 2004), the levels of this element in the shoots were higher than those found in the present study, indicating the variability in ectomycorrhizal fungi regarding the efficiency in the absorption of P. However, the increase in P absorbed may result from other characteristics, such as the solubilizer effect of the ECMf on organic phosphates, which due to the production of phosphatases, act on the $\mathrm{P}$ mineralization of the organic matter (Tedesco et al., 1995).

As previously mentioned, after three years of implementation in the field, in areas subject to the sandy process, the experiment has shown the presence of another ectomycorrhizal fungus species, the fungus Laccaria sp. (Mello, 2006), which may have colonized the eucalyptus trees, thus promoting the absorption of $\mathrm{P}$ (Table 3 and Table 4).

The Eucalyptus grandis seedlings presented significant differences regarding wood production at 960 DAP in the field (Figure 1).

The highest production of wood was found in the Entisol with fungus treatment, where more than 20,000 cubic centimeters of wood were produced, followed by the peat with fungus treatment, peat without fungus and Entisol without fungus (Figure 1). It was also found that in treatments where there had been inoculation with the UFSCPt116, from 85 to $95 \%$ higher wood productions were ob- 


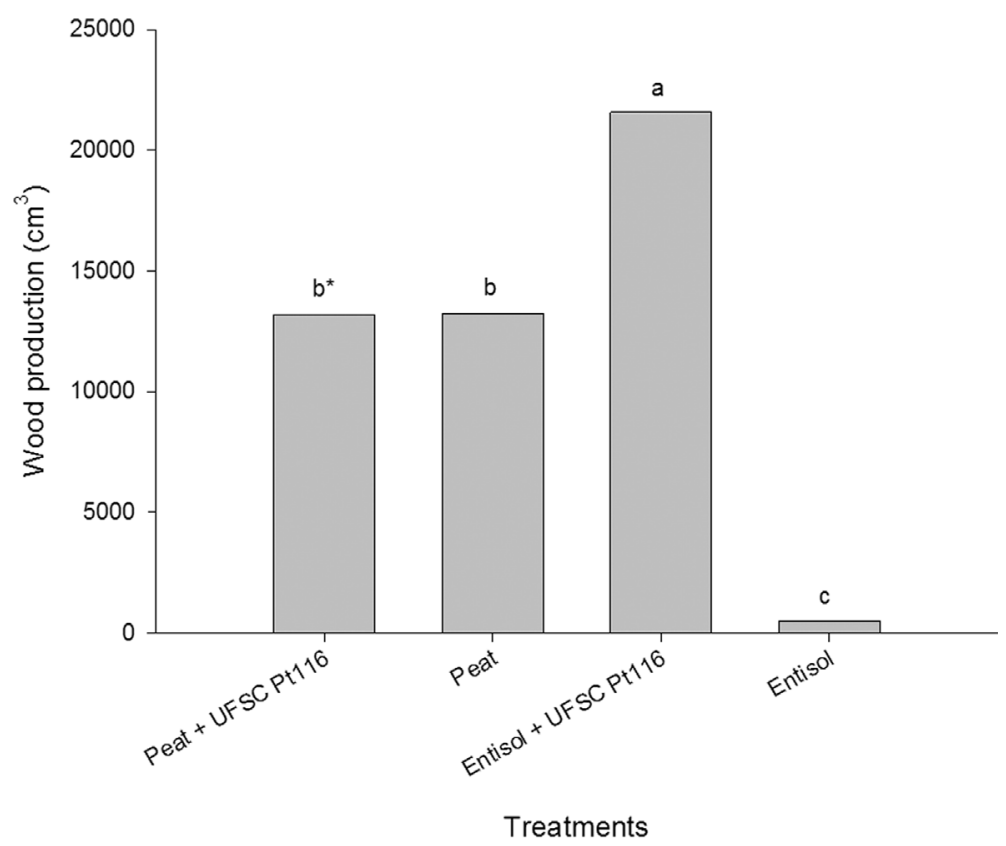

* Averages followed by the same letters in the columns do not differ statistically among each other by the Tukey test at $5 \%$ probability.

Figure 1 - Wood production of Eucalyptus grandis plants at 960 days after planting in the field, in an area subject to the sandy process in São Francisco de Assis, RS.

tained rather than in Entisol without inoculation treatment (Figure 1).

\section{Conclusion}

Eucalyptus grandis plants produced with Entisol inoculated with the ectomycorrhizal fungus Pisolithus microcarpus (UFSC-Pt116) showed higher survival rates, height and stem diameters and thus greater wood production in field conditions.

The inoculated Eucalyptus grandis plants showed high levels of nitrogen, but were not relevant regarding the levels of phosphorus and potassium and the concentrations of total soluble phosphorus fractions, inorganic phosphorus and organic phosphorus on the shoots.

\section{Acknowledgments}

To the Coordination of Improvement of Higher Education Personnel (CAPES), to the Foundation for Research Support of Rio Grande do Sul (FAPERGS), to the CNPq for the Research Productivity Program and to Mr. Nelci Salbego.

\section{References}

Alves JR, Souza O, Podlech PAS et al. (2001) Efeito de inoculante ectomicorrízico produzido por fermentação semisólida sobre o crescimento de Eucalyptus dunnii Maiden. Pesq Agrop Bras 36:307-313.
Barros NF, Brandi RM, Reis MS (1978) Micorriza em eucalipto. Uma revisão sobre a morfologia, a fisiologia e os efeitos mútuos da associação fungo-planta. R Árvore 2:130-140.

Bieleski RL (1973) Phosphate pools, phosphate transport and phosphate availability. Annu Rev Plant Physiol 24:225-252.

Bieleski RL, Ferguson JB (1983) Physiology and metabolism of phosphate and its compounds. In: Lauchli A, Bieleski RL (eds) Encyclopedia of Plant Physiology: Inorganic Plant Nutrition. Springer, Berlin, p. 422-449.

Ferreira DF (2000) Sistemas de Análises Estatística para Dados Balanceados. UFLA, Lavras.

Galli MA, Krugner TL, Gonçalves JLM et al. (1997) Effect of Eucalyptus bark compost and phosphorus on the ectomycorrhizal development of Eucalyptus plantlets inoculated in vitro with Pisolithus tinctorius. Sci For 51:7-14.

Gonçalves JLM (1994) Relatório de Pesquisas sobre Nutrição Mineral de Espécies Nativas. CESP-ESALQ-IPEF, Piracicaba.

Hogue E, Wilcox GE, Cantliffe DJ (1970) Effect of soil phosphorus levels on phosphate fractions in tomato leaves. J Amer Soc Hort Sci 95:174-176.

Marx DH (1969) The influence of ectotrophic mycorrhizal fungi on the resistance of pine roots to pathogenic infections. Antagonism of mycorrhizal fungi to root pathogenic fungi and soil bacteria. Phytopathology 59:153-163.

Mello AH (2006) Ocorrência, Caracterização e Eficiência de Fungos Micorrízicos em Eucalyptus grandis e Acacia mearnsii. PhD Thesis, Santa Maria, 236 pp.

Moller DO, Garcia IS, Geske ACSP et al. (1975) Diagnóstico Sobre a Presença de Areais na Região Sudoeste do Rio Grande do Sul. SUDESUL, Porto Alegre. 
Shimizu JY, Carvalho PER (2000) Primeira aproximação na indicação de eucaliptus para produção de madeira na região de Quaraí, RS. Bol Pesq Fl 40:101-110.

Silva RF, Antoniolli ZI, Andreazza R (2003) Produção de mudas de Pinus elliottii Engelm. micorrizadas em solo arenoso. Ci Fl 13:57-65.

Silva MA, Costa MD, Rocha RB et al. (2007) Formação de ectomicorrizas por monocários e dicários de Pisolithus sp. e interações em Eucalyptus grandis. Rev Bras Ciênc Solo 31:917-929.

Smith SE, Read DJ (1997) Mycorrhizal symbiosis. Academic Press, London.

Souza LAB (2003) Seleção de Fungos Ectomicorrízicos Eficientes para Promoção do Crescimento de Eucalyptus dunnii Maiden. M.Sc. Dissertation, 117 pp.
Souza LAB, Filho GNS, Oliveira VL (2004) Eficiência de fungos ectomicorrízicos na absorção de fósforo e na promoção do crescimento de eucalipto. Pesq Agropec Bras 39:349-355.

Tedesco MJ, Gianello C, Bissani C et al. (1995) Análise de Solo, Plantas e Outros Materiais. Editora UFRGS, Porto Alegre, $174 \mathrm{pp}$.

Trappe JM, Fogel RD (1977) Ecosystematic functions of mycorrhizae. The bellow ground ecosystem: A synthesis of plantassociated process. Rang Science 26:205-244.

Zambolim L, Barros NF (1982) Constatação de micorriza vesículo - arbuscular em Eucalyptus spp. na região de Viçosa, MG. R Árvore 6:95-97.

All the content of the journal, except where otherwise noted, is licensed under a Creative Commons License CC BY-NC. 